\title{
PENGARUH TEMPAT USAHA DAN KELENGKAPAN PRODUK TERHADAP PEMBELIAN ULANG KONSUMEN PADA SUPERMARKET BANGUNAN
}

\author{
Muhammad Ridwan ${ }^{1)}$, Noviarni ${ }^{2)}$ \\ 1,2, Dosen manajemen, Universitas Tridinanti Sumatera Selatan, Indonesia \\ 1)mhmmdridwan1961@ gmail.com, 2)noviarni1961@gmail.com
}

\begin{tabular}{l} 
INFORMASI ARTIKEL \\
\hline Submitted: \\
$01 / 12 / 2021$ \\
Revised: \\
15/12/2021 \\
Accepted: \\
25/12/2021 \\
Online-Published: \\
31/12/2021
\end{tabular}

\begin{abstract}
ABSTRAK
Penelitian ini bertujuan untuk mengetahui, menganalisis dan membuktikan Pengaruh kelengkapan produk dan tempat secara simultan dan parsial terhadap pembelian ulang di Supermarket Bangunan. Tempat penilitian berlokasi pada Supermarket Bangunan Cemerlang Jaya. Dalam penelitian ini populasinya adalah seluruh konsumen yang berbelanja di supermarket bangunan cemerlang jaya berjumlah 50 konsumen dan sampel digunakan berjumlah 50 konsumen dengan teknik sampling yang digunakan adalah sampling jenuh. Hasil yang diperoleh dari penelitian ini yaitu Terdapat pengaruh signifikan variabel tempat dan kelengkapan produk secara bersamasama terhadap variabel pembelin ulang dibuktikan dengan tabel uji $F$ yang dapat dilihat bahwa sig adalah 0,001 dari taraf signifikan tersebut berarti sig $<0,05$ yang terdapat pengaruh tempat dan kelengkapan produk secara bersama-sama terhadap pembelian ulangan. Sedangkan, secara parsial diperoleh yaitu terdapat pengaruh signifikan variabel tempat terhadap pembelian ulang, dibuktikan dari tabel analisis Uji t dapat dilihat bahwa untuk variabel tempat dengan nilai sig adalah 0,003 Dari taraf nilai signifikan (sig) $<0,05$ yang berarti variabel tempat berpengaruh terhadap pembelian ulang. Selanjutnya Terdapat juga pengaruh positif dan signifikan variabel kelengkapan produk terhadap pembelian ulang, dibuktikan dari tabel analisis Uji $t$ dapat dilihat bahwa untuk variabel kelengkapan produk, dengan nilai sig 0,000 . dari nilai taraf sigifikan (sig) <0,05 yang berarti variabel kelengkapan produk berpengaruh signifikan terhadap pembelian ulang.
\end{abstract}

Kata kunci ; tempat usaha, kelengkapan produk, pembelian ulang konsumen

\begin{abstract}
This study aims to determine, analyze and prove the effect of product and place completeness simultaneously and partially on repurchase at the Building Supermarket. The research site is located at the Cemerlang Jaya Building Supermarket. In this study, the population was all consumers who shopped at the supermarket of Gedung Cahaya Jaya totaling 50 consumers and the sample used was 50 consumers with the sampling technique used was saturated sampling. The results obtained from this study are that there is a significant effect of the place variable and the completeness of the product together on the repeat purchase variable as evidenced by the F test table which can be seen that sig is 0.001 from the significant level it means sig $<0.05$ which has the influence of place and completeness of the product together against repeat purchases. Meanwhile, partially obtained that there is a significant effect of the place variable on repeat purchases, as evidenced from the t-test analysis table it can be seen that for the place variable with a sig value of 0.003 From a significant value level (sig) $<0.05$, which means the place variable has an effect on purchases repeat. Furthermore, there is also a positive and significant effect of the product completeness variable on repeat purchases, as evidenced from the t test analysis table, it can be seen that for the product completeness variable, the sig value is 0.000. from the significant level value (sig) $<0.05$, which means that the product completeness variable has a significant effect on repeat purchases.
\end{abstract}

Keywords ; place of business, product completeness, consumer repurchase

http://www.univ-tridinanti.ac.id/ejournal/index.php/ekonomi/index 


\section{A. PENDAHULUAN}

\section{Latar Belakang}

Dalam mempelajari pemilihan lokasi usaha dikembangkan suatu pendekatan, dimana terdiri atas dua tahap, pertama pemilihan area yang akan dijadikan tempat usaha secara umum, dan kedua memilih lokasi usaha dengan pertimbangan tertentu. Pertimbangan dimaksud dibedakan menjadi dua yaitu "Musts" dan "Wants", dimana pemilik usaha menentukan lokasi usaha yang memenuhi kriteria "Musts", baru kemudian mempertimbangkan kriteria "Wants" dari lokasi usaha tersebut." (Schmenner, 1994) dalam (Fu'ad;2015).

Menurut Tjiptono (2006), pemilihan lokasi memerlukan pertimbangan yang cermat terhadap beberapa faktor berikut: (1) Akses yaitu kemudahan untuk menjangkau. Misalnya, lokasi yang dilalui atau mudah dijangkau sarana transportasi umum; (2) Visiabilitas yaitu lokasi atau tempat yang dapat dilihat dengan jelas dari jarak pandang normal; (3) Lalu-lintas menyangkut dua pertimbangan utama berikut: (a) Banyaknya orang yang lalu-lalang bias memberikan peluang besar terhadap terjadinya impulse buying, yaitu keputusan pembeli yang seringkali terjadi spontan, tanpa perencanaan, dan atau tanpa melalui usaha-usaha khusus; (b) Kepadatan dan kemacetan lalu-lintas bias pula menjadi hambatan; (4) Lingkungan yaitu daerah sekitar yang mendukung jasa yang ditawarkan

Selanjutnya, berbagai atribut yang dimiliki perusahaan merupakan potensi yang harus selalu diperhatikan dan dioptimalkan dalam menyusunstrategi yang baik guna menjaring konsumen. Kotler (2012:347) mengemukakan kelengkapan produk adalah tersedianya semua enis produk yang ditawarkan untuk dimiliki, dipakai atau dikonsumsi oleh konsumen yang dihasilkan oleh suatu produsen.
Raharjani dalam Widodo (2016:95), berpendapat bahwa konsumen cenderung memilih tempat yang menawarkan produk yang bervariasi dan lengkap menyangkut kedalaman, luas, dan kualitaskeragaman barang yang ditawarkan oleh penjual. Ketersediaan barang dalam suatu pasarswalayan meliputi variasi merk yang banyak, tipe dan ukuran kemasan barang yang dijual,macam-macam rasa dari suatu produk yang akan dibeli. Bagi sebuah pasar swalayankelengkapan barang dagangan merupakan faktor yang penting untuk menarik konsumen.Meskipun harga jual lebih tinggi dari pasar swalayan lainnya, tetapi karena lengkapnyabarang yang dijual maka, pasar swalayan ini banyak menarik para pengunjung. Semakinlengkap sebuah pasar swalayan maka semakin memenuhi kebutuhan dan keinginankonsumen, sehingga konsumen akan memutuskan untuk melakukan pembelian produkmereka.

Pembelian ulang suatu barang atau jasa disuatu perusahaan tidak hanya mengandalkan kelengkapan produk saja tetapi lokasi atau tempat yang strategis, mudah dijangkau dan sesuai dalam menempatkan tokonya di suatu kawasan yang dekat dengan keramaian dan aktivitas masyarakat merupakan fakor yang menentukan apakah konsumen akan kembali berbelanja atau tidak.

Pemilihan lokasi usaha oleh suatu organisasi atau perusahaan akan mempengaruhi minat berbelanja bagi para konsumen, dengan memiliki lahan parkir yang luas, suasana yang nyaman dan tidak macet membuat konsumen selalu betah untuk berbelanja.

Keputusan pembelian merupakan salah satu bagian pokok dalam prilaku konsumen yang mengarah kepada pembelian produk atau jasa. Dalam 
membuat sebuah keputusan pembelian, konsumen tidak terlepas dari faktorfaktor yang mempengaruhi dan memotivasi konsumen untuk melakukan pembelian. Dari faktorfaktor inilah, maka konsumen akan melakukan penilaian terhadap berbagai alternatif pilihan, dan memilih salah satu atau lebih alternatif yang diperlukan berdasarkan pertimbangan- pertimbangan tertentu (Puspa, dkk; 2017). Sehingga pembelian ulang (repeat purchase) dapat diartikan sebagai kegiatan pembelian yang dilakukan lebih dari satu kali atau beberapa kali. Jadi pembelian ulang adalah suatu proses membeli barang atau jasa untuk kesekian kalinya, setelah melakukan proses membeli sebelumnya. Keputusan pembelian ulang merupakan pengembangan dari teori keputusan pembelian konsumen.

Menurut Swastha dan Handoko (2000) faktor-faktor yang mempengaruhi keputusan pembelian berbeda-beda untuk masing-masing pembeli di samping produk yang dibeli dan saat membelinya berbeda. Faktor-faktor tersebut adalah, lokasi penjual yang strategis, tingkat harga, iklan dan promosi, penggolongan barang.

Cemerlang jaya merupakan salah satu supermarket bangunan di kota Palembang, yang kehadirannya dapat memberikan kemudahan bagi masyarakat untuk memperoleh barang-barang yang di tawarkan khususnya yang berhubungan dengan bangunan. Supermarket Cemerlang jaya menjual seluruh kebutuhan alat-alat dan bahan bangunan. Kehadiran Supermarket Cemerlang jayamerupakan tuntutan perubahan gaya hidup masyarakat, di mana Supermarket Cemerlang jayamerupakan pusat perbelanjaan kebutuhan alat-alat dan bahan bangunan ysng adadi Kota Palembang.

\section{Rumusan Masalah}

Permasalahan dalam penelitian ini adalah :

1. Apakah kelengkapan produk dan tempat berpengaruh secara simultan terhadap pembelian ulang di Supermarket Bangunan?

2. Apakah tempat berpengaruh secara parsial terhadap pembelian ulang diSupermarket Bangunan?

3. Apakah kelengkapan produk berpengaruh secara parsial terhadap pembelian ulang diSupermarket Bangunan?

\section{Tujuan Penelitian}

Tujuan dilakukannya penelitian ini adalah untuk mengetahui, menganailisis dan membuktikan :

1. Pengaruh kelengkapan produk dan tempat secara simultan terhadap pembelian ulang di Supermarket Bangunan.

2. Pengaruh tempat secara parsial terhadap pembelian ulang di Supermarket Bangunan.

3. Pengaruh kelengkapan produk secara parsial terhadap pembelian ulang di Supermarket Bangunan.

\section{Kerangka Berfikir}

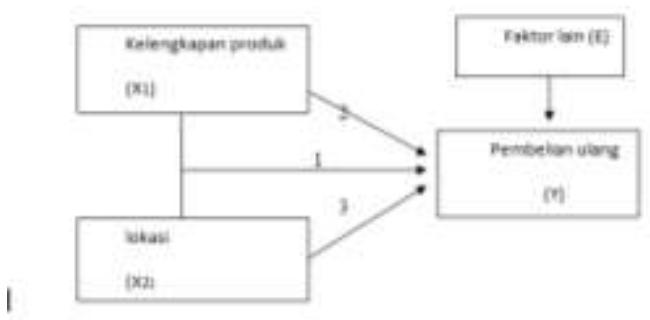

Gambar 1. Kerangka Berpikir

\section{Hipotesis Penelitian}

Pengertian hipotesis menurut Sugiyono (2012:51) adalah jawaban 
sementara terhadap rumusan masalah penelitian, dimana rumusan masalah penelitian telah dinyatakan dalam bentuk kalimat pertanyaan. Hipotesisi merupakan dugaan sementara yang mungkin benar dan mungkin salah, sehingga dapat dianggap atau dipandang sebagai kesimpulan yang sifatnya sementara, sedangkan penolakan atau penerimaan suatu hipotesis tersebut tergantung dari hasil penelitian terhadap faktor-faktor yang dikumpulkan, kemudian diambil suatu kesimpulan.

Berdasarkan kerangka berfikir di atas maka dapat diajukan hipotesis penelitian yaitu :

1. Diduga kelengkapan produk dan tempat berpengaruh secara simultan terhadap Pembelian Ulang Konsumen di Supermarket Bangunan.

2. Diduga Kelengkapan Produk berpengaruh secara parsial terhadapPembelian Ulang Konsumen di Supermarket Bangunan.

3. Diduga tempat berpengaruh secara parsial terhadap Pembelian Ulang Konsumen di Supermarket Bangunan.

\section{B. METODE PENELITIAN}

\section{Tempat Penelitian}

Tempat penilitian berlokasi pada Supermarket Bangunan Cemerlang Jaya yang beralamat di JL. Sultan Mahmud Badaruddin II No. 728 E KM 12 Palembang

\section{Populasi, Sampel, Sampling}

Menurut Sugiyono (2012:115) populasi adalah wilayah generasi yang terdiri atas objek maupun subjek yang mempunyai kualitas dan karakterisitik tertentu yang ditetapkan peneliti untuk dipelajari dan kemudian ditarik kesimpulannya. Dalam penelitian ini populasinya adalah seluruh konsumen yang berbelanja di supermarket bangunan cemerlang jaya.

Sampling adalah teknik tertentu yang digunakan oleh peneliti untuk mengambil sampel dari populasi. Dalam penelitian ini teknik sampling yang digunakan adalah sampling jenuh. Sampling jenuh adalah teknik penentuan sampel bila semua anggota populasi digunakan sebagai sampel (Sugiyono, 2012:168), dimana populasi dalam penelitian ini berjumlah 50 konsumen dan sampel digunakan berjumlah 50 konsumen.

\section{Instrumen Penelitian}

Untuk mendapatkan data-data yang berkaitan dengan pengaruh tempat dan kelengkapan produk terhadap pembelian ulang konsumen di supermarket bangunan cemerlang jaya digunakan instrumen berupa kuisioner dengan mengukur menggunakan skala likert. Dalam pengelolaan data yang berbentuk kuisioner diperlukan uji validitas dan reabilitas.

a. Uji Validitas 
Menurut Sugiyono (2012:110) validitas adalah tingkat yang digunakan untuk menjawab pertanyaan instrumen apakah mampu mengukur apa yang hendak diukur atau dengan kata lain tingkat kemampuan suatu instrumen untuk mengungkapkan sesuatu menjadi sasaran pokok pengukuran yang dilakukan dengan instrumen tersebut.

Setiap item dikatakan valid apabila mempunyai dukungan yang besar terhadap skor total. Skor pada setiap item menyebabkan skor total menjadi tinggi dan rendah. Dengan kata lain dapat dikemukakan disini bahwa setiap item memiliki validitas yang tinggi jika skor total mempunyai kesejajaran dengan skor total. Kesejajaran ini dapat diartikan dengan korelasi sehingga mengetahui untuk mengetahui validitas item digunakan rumus korelasi.

Untuk mengukur validitas instrumen tempat, kelengkapan produk dan Pembelian ulang dilakukan uji instrumen dengan menggunakan Konsumen sebagai responden. Validitas instrumen ketiga variabel dicari dengan menghitung data dengan rumus dalam program SPSS.

Instrumen yang valid berarti instrumen tersebut dapat digunakan untuk mengukur apa yang seharusnya diukur (Sugiyono 2012:172). Penelitian ini menggunakan pengukuran dengan melihat output pearson correlation.

b. Uji Reliabilitas

Menurut Sugiyono (2012:121) instrumen yang reliable berarti instrumen yang bila digunakan beberapa kali untuk mengukur objek yang sama akan menghasilkan data yang sama. Uji reliabilitas digunakan untuk mengetahui konsistensi alat ukur yang biasanya menggunakan kuisioner.

\section{Uji Hipotesis}

\section{Uji Secara Signifikan digunakan Uji F}

Untuk mengetahui ketepatan variabel yang digunakan dalam model, digunakan hipotesis sebagai berikut :

- Ho : b1 b2 = 0, artinya tidak ada pengaruh tempat dan kelengkapan produk secara bersama-sama dalam kemauan Konsumen untuk Pembelian ulang di supermarket bangunan cemerlang jaya.

- Ho : b1 b2 \# 0, artinya terdapat ada pengaruh tempat dan kelengkapan secara bersama-sama dalam kemauan Konsumen untuk Pembelian ulang di supermarket bangunan cemerlang jaya.

- Level of Significance (à) = $5 \%$ atau 0,05

- Kriteria pengujian Jika F sig > a $(0,05)$, maka Ho diterima 
Jika F sig < a $(0,05)$, maka Ho ditolak

\section{Uji secara parsial digunakan Uji-t}

Uji digunakan untuk menguji apakah pertanyaan hipotesis benar (terbukti) atau tidak.

- Ho : b1 = 0, artinya tidak ada pengaruh tempat dalam meningkatkan pembelian ulang konsumen di supermarket bangunan cemerlang jaya.

- Ho : b1 \# 0, artinya terdapat pengaruh kelengkapan produk dalam meningkatkan pembelian ulang konsumen di supermarket bangunan cemerlang jaya..

- Level of Significance (a) = 5\% atau 0,05

- Kriteria pengujian

t.sig $>0,05$ artinya Ho diterima

t.sig $<0,05$ artinya Ho ditolak

- Ho : b2 = 0, artinya tidak ada pengaruh tempat dalam meningkatkan pembelian ulang konsumen di supermarket bangunan cemerlang jaya..

- Ho : b2 \# 0, artinya terdapat ada pengaruh Kelengkapan produk dalam meningkatkan pembelian ulang konsumen di supermarket bangunan cemerlang jaya.

- Kriteria pengujian t.sig $>0,05$ artinya Ho diterima t.sig $<0,05$ artinya Ho ditolak

\section{HASIL DAN PEMBAHASAN}

\section{Uji Validitas}

Digunakan untuk menguji sejauh mana ketepatan alat pengukur dapat mengungkapkankonsep gejala atau kejadian yang diukur. Item kuesioner dinyatakan valid apabila nilai $r$ hitung $>r$ tabel (n-2). Pengujianvaliditas selengkapnya dapat dilihat gambar sebagai berikut ini:

Tabel 1. Hasil Uji Validitas Variabel tempat (X1)

\begin{tabular}{|l|l|l|l|l|}
\hline No & Variabel/ indikatornya & r hitung & r tabel & Keterangan \\
\hline 1 & Pernyataan 1 & 0,685 & 0,297 & Valid \\
\hline 2 & Pernyataan 2 & 0,829 & 0,297 & Valid \\
\hline 3 & Pernyataan 3 & 0,646 & 0,297 & Valid \\
\hline 4 & Pernyataan 4 & 0,942 & 0,297 & Valid \\
\hline 5 & Pernyataan 5 & 0,792 & 0,297 & Valid \\
\hline 6 & Pernyataan 6 & 0,578 & 0,297 & Valid \\
\hline 7 & Pernyataan 7 & 0,885 & 0,297 & Valid \\
\hline 8 & Pernyataan 8 & 0,942 & 0,297 & Valid \\
\hline
\end{tabular}


Tabel 2 Hasil Uji Validitas

Variabel kelengkapan produk (X2)

\begin{tabular}{|l|l|l|l|l|}
\hline No & Variabel/ indikatornya & r & r tabel & Ketera \\
\hline 1 & Pertanyaan 1 & & ngan \\
\hline 2 & Pertanyaan 2 & 0,645 & 0,297 & Valid \\
\hline 3 & Pertanyaan 3 & 0,679 & 0,297 & Valid \\
\hline 4 & Pertanyaan 4 & 0,709 & 0,297 & Valid \\
\hline 5 & Pertanyaan 5 & 0,708 & 0,297 & Valid \\
\hline 6 & Pertanyaan 6 & 0,642 & 0,297 & Valid \\
\hline 7 & Pertanyaan 7 & 0,617 & 0,297 & Valid \\
\hline 8 & Pertanyaan 8 & 0,419 & 0,297 & Valid \\
\hline
\end{tabular}

Tabel 3. Hasil UjiValiditas Pembelian Ulang (Y)

\begin{tabular}{|l|l|l|l|l|}
\hline No & Variabel/indikatornya & r hitung & r tabel & Keterangan \\
\hline 1 & Pertanyaan 1 & 0,441 & 0,297 & Valid \\
\hline 2 & Pertanyaan 2 & 0,667 & 0,297 & Valid \\
\hline 3 & Pertanyaan 3 & 0,324 & 0,297 & Valid \\
\hline 4 & Pertanyaan 4 & 0,347 & 0,297 & Valid \\
\hline 5 & Pertanyaan 5 & 0,299 & 0,297 & Valid \\
\hline 6 & Pertanyaan .6 & 0,383 & 0,297 & Valid \\
\hline 7 & Pertanyaan 7 & 0,835 & 0,297 & Valid \\
\hline 8 & Pertanyaan 8 & 0,432 & 0,297 & Valid \\
\hline
\end{tabular}

Tabel tersebut terlihat bahwa korelasi antara masing-masing indikator terhadap total skor konstruk dari setiap variabel menunjukan hasil signifikan, dan 
menunjukan bahwar $\mathrm{r}$ hitung >r tabel. Sehingga dapat disimpulkan bahwa semua item pertanyaan dinyatakan valid.

\section{Uji Realibilitas}

Uji realibilitas digunakan untuk menguji sejauh mana kendala suatu alat untuk dapat digunakan lagi untuk penelitian yang sama. Pengujian realibilitas dalam penelitian ini adalah dengan menggunakan rumus alpha. Hasil penguji realibilitas untuk masing-masing variabel dapat dilihat berikut ini .

\section{Reliability Statistics}

\section{Uji Realibilitas Kelengkapan Produk (X1)}

Untuk melihat kerealibilitas pada variabel kelengkapan produk (X1) yang telah dilakukan pengisian kuesioner oleh 60 orang responden menjawab 8 pertanyaan tersebut dijadikan sebagai indikator terhadap variabel kelengkapan produk (X1).

Tabel 4. Hasil Penguji Realibilitas Kelengkapan Produk

\begin{tabular}{|l|l|}
\hline Cronbach's Alpha & N of Items \\
\hline .932 & 10 \\
\hline
\end{tabular}

Dari hasil analisis diatas dapat nilai cronbacch's alpha sebesar 0,932.Maka dapat disimpulkan bahwa butir-butir instrument penelitian tersebut reliabel.

\section{Uji Realibilitas Tempat ( X2 )}

Untuk melihat ke realibilitas pada variabel Tempat (X2) yang telah dilakukan pengisian kuesioner oleh 60

Reliability Statistics

\begin{tabular}{|l|l|}
\hline Cronbach's Alpha & N of Items \\
\hline .790 & 12 \\
\hline
\end{tabular}

orang responden dengan menjawab 8 pertanyaan yang valid. $\mathrm{Ke} 8$ item pertanyaan tersebut dijadikan sebagai indikator terhadap variabel Tempat (X2).

Tabel 5. Hasil Penguji Realibilitas Tempat(X2)
Dari hasil anasis diatas didapat cronbach's alpha sebesar 0,790. Maka dapat disimpulkan bahwa butir-butir instrument penelitian tersebut reliabel.

\section{Uji Realibilitas Kinerja Pembelian Ulang ( Y )}

Untuk melihat ke realibilitas pada variabel Pembelian ulang yang telah 
dilakukan pengisian kuesioner oleh 60 orang responden pertanyaan yang valid.

Ke 8 item pertanyaan tersebut dijadikan sebagai indikator terhadap variabel kinerja Pembelian Ulang ( Y ).
Tabel 6. Hasil Penguji Realibilitas Pembelian Ulang ( Y )

\section{Reliability Statistics}

\begin{tabular}{|l|l|}
\hline Cronbach's Alpha & N of Items \\
\hline .845 & 14 \\
\hline
\end{tabular}

Dari hasil analisis diatas nilai cronbac's alpha sebesar 0,845.Maka dapat disimpulkan bahwa butir-butir instrumen penelitian tersebut reliabel.

Hasil penguji realibilitas tersebut menunjukan bahwa hasil masing-masing variabel mempunyai koefisien alpha yang cukup besar yaitu diatas 0,6 sehingga dapat dikatan reliabel.

\section{Uji F (Penguji Hipotesis Secara Simultan)}

Pengaruh variabel kelengkapan produk dan tempat secara bersama-sama terhadap pembelian ulang.

Untuk menguji pengaruh variabel bebas secara bersama-sama dengan ANOVA $^{\mathrm{b}}$

\begin{tabular}{|ll|l|l|l|l|l|}
\hline \multicolumn{2}{|l|}{ Model } & $\begin{array}{l}\text { Sum } \\
\text { Squares }\end{array}$ & of & Mean Square & F & Sig. \\
\hline $1 \quad$ & Regression & 1189.331 & 2 & 594.665 & 24.457 & $.000^{\mathrm{a}}$ \\
& $\begin{array}{l}\text { Residual } \\
\text { Total }\end{array}$ & 996.919 & 41 & 24.315 & & \\
& 2186.250 & 43 & & & \\
\hline
\end{tabular}

a. Predictors: (Constant), variabel.2, variabel.1 
ANOVA $^{\mathrm{b}}$

\begin{tabular}{|ll|l|l|l|l|l|}
\hline \multicolumn{2}{|l|}{ Model } & $\begin{array}{l}\text { Sum } \\
\text { Squares }\end{array}$ & of & Mean Square & F & Sig. \\
\hline 1 & Regression & 1189.331 & 2 & 594.665 & 24.457 & $.000^{\mathrm{a}}$ \\
& $\begin{array}{l}\text { Residual } \\
\text { Total }\end{array}$ & 996.919 & 41 & 24.315 & & \\
& 2186.250 & 43 & & & \\
\hline
\end{tabular}

b. Dependent Variable: variabel.y

Penguji hipotesis pengaruh variabel kelengkapan produk dan tempat terhadap pembelian ulang menggunakan ( uji-F) adapun kriteria pengujiannya adalah :

1. Ho : b1,b2 =0 variabel kelengkapan produk dan tempat secara bersama-sama tidak berpengaruh terhap pembelian ulang.

2. Ha: b1,$b 2 \neq 0 \quad$ variabel kelengkapan produk dan tempat secara bersama-sama berpengaruh terhadap pembelian ulang.

3. Ho ditolak jika sig $>0,05$

4. Ha diterima jika sig $<0,05$

KarenaF sig< 0,05 maka kesimpulan menolak Ho dan merima Ha.Pengujian variabel bebas secara bersama-bersama terhadap variabel terikatnya dilakukan dengan menggunakan uji $F$ hasil perhitungan statistic menunjukan nilai sig 0,000 dengan menggunakan batas signifikansi 0,05, maka diperoleh nilai signifikansiyang diteliti tersebut lebih kecil 0,05 hal ini berarti hipotesis menyatakan bahwa secara simultan variabel kelengkapan produk dan tempat berpengaruh terhadap Pembelian ulang.

\section{Uji t (Penguji Hipotesis Secara Parsial)}

Hipotesis kelengkapan produk dan tempat diuji kebenarannyadengan menggunakan uji parsial pengujian ini dilakukan dengan melihat taraf signifikansi (value) jika taraf signifikansi yangdiberikan perhitungan dibawah 0,05 maka hipotesis diterima sebaliknya jika taraf signifikansi hasil hitung lebih besar 0,05 maka hipotesis ditolak.

Tabel 8. Hasil Uji t Secara Parsial

Coefficients $^{\mathrm{a}}$ 


\begin{tabular}{|lr|l|l|l|l|l|}
\hline \multicolumn{2}{|c|}{} & \multicolumn{2}{|l|}{\begin{tabular}{l} 
Unstandardized \\
\multicolumn{2}{|l|}{ Coefficients }
\end{tabular}} & $\begin{array}{l}\text { Standardized } \\
\text { Coefficients }\end{array}$ & & \\
\cline { 2 - 5 } & B & Std. Error & Beta & T & Sig. \\
\hline 1 & variabel.1 & .365 & .114 & .380 & 3.209 & .003 \\
& variabel.2 & .495 & .122 & .482 & 4.068 & .000 \\
\hline
\end{tabular}

a. Dependent Variable: variabel.y

\section{Pengaruh Variabel Kelengkapan Produk Terhadap Pembelian Ulang}

Penguji hipotesis pengaruh kelengkapan produk terhadap pembelian ulang ini menggunakan uji parsial

(uji t)adapun kriteria pengujinya adalah:

1. Ho : $\mathrm{b} 1=0$ kelengkapan produk tidak berpengaruh signifikan terhadap pembelian ulang.

2. Нa : b1 $\neq 0$ kelengkapan produk berpengaruh signifikan terhadap pembelian ulang

3. Ho ditolak, jika sig $>0,05$.

4. Ha diterima jika sig $<0,05$.

Karena sig $t<0,05$ maka kesimpulan menolak Ho dan menerima Ha. Dari tabel uji t dilihat bahwa nilai sig untuk variabel kelengkapan produk adalah 0,03 Dari taraf signifikansitersebut berarti sig $<0,05$ yang berarti variabel kelengkapan produk berpengaruh signifikan terhadap pembelian ulang.

\section{Pengaruh Variabel Tempat Terhadap Pembelian Ulang}

Penguji hipotesis pengaruh variabel tempat terhadap pembelian ulang ini menggunakan uji parsial (uji t) adapun kriteria pengujinya adalah:
1. Ho : $\mathrm{b} 2=0$ tempat tidak berpengaruh signifikan terhadap pembelian ulang.

2. Ha : $\mathrm{b} 2 \neq 0$ tempat berpengaruh signifikan terhadap pembelian ulang

3. Ho diterima jika, sig $>0,05$

4. Ha ditolak jika, sig $<0,05$

Karena sig $t \quad<0,05 m a k a$ dapat kesimpulan menolak Ho dan menerima Ha. Dari tabel uji t dilihat bahwa nilai sig untuk variabel tempat adalah 0,000 dari taraf nilai signifikansi tersebut berarti sig 0,05 variabel tempat berpengaruh signifikan terhadap pembelian ulang.

\section{SIMPULAN DAN SARAN Simpulan}

1. Terdapat pengaruh signifikan variabel tempat dan kelengkapan produk secara bersama-sama terhadap variabel pembelin ulang. Dari tabel uji $\mathrm{F}$ diatas dapat dilihat bahwa sig adalah 0,001 dari taraf signifikan tersebut berarti sig $<0,05$ yang terdapat pengaruh tempat dan kelengkapan produk secara bersama-sama terhadap pembelian ulangan.

2. Terdapat pengaruh signifikan variabel tempat terhadap 
pembelian ulang, dari tabel analisis $\mathrm{Uji} \mathrm{t}$ dapat dilihat bahwa untuk variabel tempat dengan nilai sig adalah 0,003 Dari taraf nilai signifikan (sig) $<0,05$ yang berarti variabel tempat berpengaruh terhadap pembelian ulang.

3. Terdapat pengaruh positif dan signifikan variabel kelengkapan produk terhadap pembelian ulang, dari tabel analisis Uji t dapat dilihat bahwa untuk variabel kelengkapan produk ,dengan nilai sig 0,000 . dari nilai taraf sigifikan $(\mathrm{sig})<0,05$ yang berarti variabel kelengkapan produk berpengaruh signifikan terhadap pembelian ulang.

\section{Saran}

1. Hasil uji R2 masih ada variabelvariabel lain yang harus diperhatikan dalam penelitian ini. Penelitian-penelitian lebih lanjut hendaknya variabel lain yang dapat mempengaruhi pembelian ulang, karena dengan semakin strategisnya tempat dan lengkap nya produk maka semakin bagus untuk kemajuan suatu perusahaan tersebut.

\section{E. DAFTAR RUJUKAN}

Fu'ad, Eko Nur; 2015; Pengaruh Pemilihan Lokasi terhadap Kesuksesan Usaha Berkala Mikro/Kecil di Komplek Shopping Center Jepara; Jurnal Media Ekonomi dan Manajemen vol. 30 no. 1. Januari 2015

Kotler, Philip and Gary Amstrong. (2012) Priciples of Marketing Global 14th edition. New Jersey: Prentice.
Puspa, Rani, dkk; 2017; Pengaruh Harga dan Lokasi terhadap Keputusan Pembelian (Studi Kasus pada Perumahan Cianjung River Park Serang, Banten; Jurnal Ilmiah Manajemen Bisnis, Volume 3, No. 02. Juli 2017

Swastha, Basu dan T. Hani Handoko, (2000) Manajemen Pemasaran "Analisa perilaku konsumen". Edisi pertama cetakan ketiga. BPFEYogyakarta, Yogyakarta

Tjiptono, Fandy. (2006) Edisi Pertama. Yogyakarta: Andi.

Widodo. Sri. 2016. Manajemen Sumber Daya Manusia: Teori, Perencanaan Strategi, Isu-isu Utama dan Globalisasi, Manggu Media, Bandung 